University of Wollongong

Research Online

Faculty of Law, Humanities and the Arts Papers (Archive)

Faculty of Arts, Social Sciences \& Humanities

$1-1-2014$

A Secular Australia? Ideas, politics and the search for moral order in nineteenth and early twentieth century Australia

Gregory Melleuish

University of Wollongong, gmelleui@uow.edu.au

Follow this and additional works at: https://ro.uow.edu.au/lhapapers

Part of the Arts and Humanities Commons, and the Law Commons

Research Online is the open access institutional repository for the University of Wollongong. For further information contact the UOW Library: research-pubs@uow.edu.au 


\title{
A Secular Australia? Ideas, politics and the search for moral order in nineteenth and early twentieth century Australia
}

\begin{abstract}
This article argues that the relationship between the religious and the secular in Australia is complex and that there has been no simple transition from a religious society to a secular one. It argues that the emergence of apparently secular moral orders in the second half of the nineteenth century involved what Steven D. Smith has termed the 'smuggling in' of ideas and beliefs which are religious in nature. This can be seen clearly in the economic debates of the second half of the nineteenth century in Australia in which a Free Trade based on an optimistic natural theology battled with a faith in Protection which had powerful roots in a secular form of Calvinism espoused by David Syme. The article concludes with an analysis of twentieth-century historian W. K. Hancock's comparison of the medieval commonwealth and Machiavelli, concluding that Hancock found both the Free Trade and the Protectionist visions of moral order to be inadequate.
\end{abstract}

\section{Keywords}

early, nineteenth, order, moral, century, search, twentieth, politics, ideas, australia, secular

\section{Disciplines}

Arts and Humanities | Law

\section{Publication Details}

Melleuish, G. C. (2014). A Secular Australia? Ideas, politics and the search for moral order in nineteenth and early twentieth century Australia. Journal of Religious History, 38 (3), 398-412. 


\title{
A Secular Australia? Ideas, Politics
}

\author{
and the Search for Moral Order in
}

\section{Nineteenth and Early Twentieth}

\section{Century Australia}

The issue of secularisation and its relationship to political ideas in Australia cannot be discussed properly without some consideration regarding the nature of religion. There are these two gigantic all-encompassing and totalising terms 'religion' and 'secular' that are then played off against each other as if one must stand in either one camp or the other. There is also this other term 'modern' or 'modernity' that is used to indicate that there is a qualitative difference between where we are now and where we were in the past. There is a narrative that says that to be modern is to be secular and that religion is something that adheres to 'primitive' people, be they in the non-European world or living in that strange period called the 'Middle Ages'. Under these circumstances it is no wonder that those who are castigated as not being 'modern' are also described as being religious and feudal. ${ }^{1}$

As shall be seen this characterisation was problematic for at least one very important Australian political thinker of the twentieth century, W K Hancock who wrote in 1936 that 'The English are

\footnotetext{
${ }^{1}$ Kathleen Davis, Periodization and Sovereignty: How Ideas of Feudalism \& Secularization Govern the Politics of Time, (Philadelphia: University of Pennsylvania Press, 2008)
} 
mediaeval because of their intense pre-occupation with justice. ${ }^{2}$ If the English were mediaeval, and consequently not modern and therefore 'religious', then surely the same can be said of an Australia which considered itself to be $98 \%$ British in the 1930s. Hancock was a key figure in the development of Australian political ideas; he was also Australia's pre-eminent historian of the first half of the twentieth century. A case can be put that arguments about politics in Australia tend to take the form of arguments about history. ${ }^{3}$ This perhaps should not surprise us in a settler society but it should also make us aware that if, following Davis, secularisation is one of the keys to the politics of time, then political ideas in Australia cannot be understood without an appreciation of those politics.

Hancock was concerned with the issue of what is best described as 'moral order'. By moral order is meant the moral framework within which people act and which they use to justify their understandings of justice. As shall be discussed, for Hancock this was not a simple matter because both the mediaeval framework, which might be described in terms of commonwealth, and the modern framework, which he linked to the ideas of Machiavelli, had problems. Hancock appreciated that ideas regarding moral order had their origins in the past; they were not just created out of nothing. The argument of this paper is that in an apparently 'secular' Australia ideas about moral order did not, like Athena, emerge pristine out of the head of the God of Modernity, but were re-worked versions of much older religious ideas. To adapt the term of Steven D Smith, religious ideas were 'smuggled in' from the past to what look like on the surface to be purely secular understandings of the world. Smith argues that secular discourse often

\footnotetext{
${ }^{2}$ W K Hancock, Politics in Pitcairn and other essays, Macmillan, London, 1947, pp. 41-2

${ }^{3}$ Gregory Melleuish, 'The Dubious Future of History,' Quadrant, 54.5 (2010) 8
} 
relies on 'inadmissible notions such as those that animated premodern moral discourse' without acknowledgement because 'our deepest convictions rely on such notions. ${ }^{4}$ To help explain how such 'smuggling' occurred in the Australian context it is first necessary to say something about the 'politics' of time that the Australian colonists employed to understand their circumstances. The obvious means for those who had either been exiled to Australia or who had come of their own choice was to view the world in terms of progress and development. For them there was only something to build in a land in which they often did not feel really at home. In their eyes the only way to go was forward, towards a more modern and better world. It is true that nineteenth century Australian colonists generally had a vision of themselves as advancing the cause of modern civilisation and therefore emancipating themselves from the timeless world that had preceded it. The following statement from John West, later editor of the Sydney Morning Herald in 1854, indicates how committed the colonists were to a politics of time founded on progress:

a broad line of demarcation distinguishes the Oriental nations from the European nations. Progress distinguishes the one; and stereotyped stationariness the other. ${ }^{5}$

The Australian colonists understood themselves to be modern in the sense that they were living in the age of railways, science and increased material wealth. But that did not mean that they thought of themselves as inhabiting a secular age. Consider this statement coming at the end of a catalogue of the material advances of New South Wales in 1851:

Let them become so in that genuinely progressive spirit, which, seeking only in its worldly politics to ameliorate and improve the condition of humanity, shall leave to the pure and

\footnotetext{
${ }^{4}$ Steven D Smith, The Disenchantment of Secular Discourse, (Cambridge Mass: Harvard University Press, 2010) 26

${ }^{5}$ John West, Union Among the Colonies, (Melbourne: Australian Scholarly Publishing, 2001$), 58$.
} 
simple Christianity which is the sole beautifier and perfector of all human institutions, that regeneration of our race which is promised and foretold. ${ }^{6}$

When one reads rhetoric about material progress it is invariably linked to statements about moral and spiritual improvement and the importance of religion as an element of progress.

The Australian colonists may have seen their story as the story of emancipation and the triumph of the modern (which is not to say that their understanding was correct), but it is important to understand exactly what that story meant. It need not mean that humanity was about to enter a world without God or religion. It could just as easily mean:

This is pre-eminently the age of faith: not, indeed, in outward forms, and material symbols, but in the deep inner truths that they embody, the realty of God and Virtue, and His promise of aid to all who seek Him patiently and aright. The earnest of the promise we have already: its perfect fulfillment we must be content to see afar off. ${ }^{7}$

For Woolley this new age was an age of democracy and justice. It was an age in which humanity would be fulfilled through religion not emancipated from religion.

At this point we need to ask quite specific questions and these are:

- what kind of secular and

- what kind of religion.

There is an ambiguity about modernity and being 'modern'; the same applies to the application of the ideas of both secular and religion in the Australian setting. It is never very clear what the two words actually mean. If Australia is to be seen as a secular society then we must ask if this means the absence of a state sponsored religion or the dominance of a set of values that can be

\footnotetext{
${ }^{6}$ Charles St Julian \& Edward Kennedy Sylvester, The Productions, Industry, and Resources of New South Wales, (Sydney, 1851), 281

${ }^{7}$ John Woolley, Lectures Delivered in Australia, (London, 1862), 105
} 
described as 'secular' (in the Australian case this is generally understood in terms of the triumph of utilitarianism) or a general indifference to the Churches and their pretensions. As Robert Markus argued in his recent Christianity and the Secular, which deals with late antiquity, it may be preferable to have a secular situation in which there are a variety of competing religions to a 'religious society' where one religion has a monopoly of belief and practice. ${ }^{8}$ A religious society should not be confused with one in which a single institution exercises a monopoly over religion. There has never been a religious monopoly in Australia; there has never been an established church. There has always been a measure of religious pluralism combined with a measure of indifference, which means that no religious group can monopolise the public sphere. Under these circumstances it is possible to have a public sphere that is both secular, in the sense that it is free of the dominance of a particular religion or version of a religion, and religious, in the sense that it is informed by the religious values of those who participate in it.

The other appropriate question to ask in Australia is 'what kind of religion'. George Shaw has made two points both of which are valid:

- Australian religion, and he meant Christianity, has always been of a moralistic caste. ${ }^{9}$ It was first used as a tool to 'reform' convicts, and since that time its major concern has been with the reformation of manners. It has not been overly concerned with things of the mind or of the spirit. One would suspect that a moralising variety of Islam would find much that is congenial in Australia.

\footnotetext{
${ }^{8}$ Robert A Markus, Christianity and the Secular, ( Notre Dame: University of Notre Dame Press, 2006), 71-91

${ }^{9}$ George Shaw, 'Beyond discipline?: the historical context of theological thought in Australia,' St Mark's Review, 133, (1988): 14-20
} 
- Humanism in Australia has been of a sentimental rather than an intellectual nature. ${ }^{10} \mathrm{It}$ is based on feeling, and moreover, I would argue, that too often has its roots in a feeling of moral self-righteousness that owes a lot to the peculiar nature of Australian religion. There is nothing in Australia really comparable with the American outpourings of the spirit as exemplified by the Second Great Awakening of the nineteenth century. By and large, Australian religion has been largely 'churched', rationalistic and moralistic. Outside of particular examples, such as Bishop Burgmann and his impact on Anglicanism, it has not been much interested with the things of the mind or intellect. If Australia, as often is claimed, was 'born modern' this means that it saw itself as having escaped the clutches of the past. As has already been argued, nineteenth century Australian colonists often saw themselves as being in the vanguard of the spread of modern civilisation. But it can be understood to mean much more than this. It can also mean that there was a break with the past as Australians did not bring with them from Britain and elsewhere the artefacts of an old culture. Instead they brought the new fangled ideas of the nineteenth century such as utilitarianism and liberalism. They sit on this side of the French Revolution and inherited a world cleansed of the supposed absurdities of the ancien regime. Or perhaps they could be viewed as bringing to Australia knowledge of the past that had been reduced to recipes and formulae ready to be applied without any concern for context. Was Australia born modern? Was it a 'new' culture that lacked the presence of the past? At times it is true that the colonists felt the absence of a past such as existed in old buildings, ruins covered in moss and ivy, fragments of recollection of an older and more traditional world. That is not to say that colonists arriving in Australia did so with their minds and souls stripped clean of their heritage. So what did they do? They attempted to re-create an old world in a new

\footnotetext{
${ }^{10}$ George Shaw, 'Bicentennial Writing: Revealing the Ash in the Australian Soul,' in George Shaw (Ed) 1988 and all that: New Views of Australia's Past, (St Lucia: University of Queensland Press,1988), 1-18
} 
one. They built traditional churches and universities. They wanted to combine the progress of the nineteenth century with the stability of an Anglo-Saxon past. This can be seen very clearly in a report that a young George Reid wrote on New South Wales for the Centenary Exposition of the United States in 1876 . He describes the colony as 'a country in which he might seize all the opportunities a new world affords, without losing the comforts and advantages of civilisation.' The desire for balance can be seen in Reid's characterisation of colonial society which he described as follows, 'If we turn to the social fabric, the eye rests upon a community young yet conservative, pushing yet generous, free yet orderly.' Reid lists the major public buildings of Sydney. The styles are invariably, Gothic, Roman, Italian, Florentine, but only next to two of them does he also use the word 'modern'. ${ }^{11}$

The desire to be modern and progressive was tempered by a wish to be orderly and traditional. The colonial mentality is quite complex in its nature. It wants to be both free and progressive while at the same time hanging onto those cherished traditions that they have brought from the old world. In fact Australians could be free and progressive because those were the very traditions that they had brought with them.

There was, however, one factor that inclined the Australian colonists to make their public life secular. This was the reality of a variety of Christian denominations in the colonies. Australia has always been religiously pluralist. One of the most important themes of Australian history, particularly in the nineteenth century, was working out measures to accommodate these religious differences so that they did not sour public life. There were occasions when sectarian

\footnotetext{
${ }^{11}$ George Reid, An Essay on New South Wales, The Mother Colony of the Australias, (Sydney, 1876), 11, 125,146
} 
strife could threaten to turn nasty such as in the wake of the unsuccessful assassination attempt on Prince Alfred in $1867 .^{12}$

One simple way of managing religious pluralism and the potential conflict that it was seen to entail, was to attempt to keep religious matters out of public life altogether. One example of such a situation can be seen in the 1859 New South Wales elections when Daniel Deniehy attempted to blame religious issues for his failure to be elected as member for West Sydney. Deniehy was immediately attacked by the liberal newspaper the Empire for attempting to bring religious matters of this nature into an election campaign. Mr Deniehy, it commented, "had the excessively bad taste to make...(the assertion) that he owed his rejection to the fact of his being a Catholic., ${ }^{13}$

This did not mean that religion was not recognised as an important aspect of colonial life. What it did mean was that it was so important that it needed to be managed in the public interest. One way to manage it was to confine it to the private lives of individuals as much as possible. If what mattered about a public man was his character and capacity to deal with public affairs then accidental matters such as his religious affiliation were irrelevant. For the Empire the problem with Mr Deniehy was not that he was a Catholic but that he had chosen to become a renegade liberal, or as it put it colourfully 'Mr Deniehy is the unprincipled demagogue who, incensed at his defeat (a defeat, the natural consequences of his political treachery) played upon the passions of an ignorant mob, regardless of the consequences, or the public peace. ${ }^{14}$ The other strategy, and it can be seen that it follows from that of making a distinction between a man's character and his religious beliefs, was to separate out what might be considered the

\footnotetext{
${ }^{12}$ See John Hirst, The Strange birth of Colonial Democracy, (Sydney: Allen \& Unwin, 1988), $72-7$.

${ }^{13}$ Empire, 16 June 1859, 4

${ }^{14}$ Empire, 23 June 1859, 6
} 
dogmatic and ethical parts of Christianity, such that it was assumed that while there was rough agreement amongst all parties on the ethical there were irreconcilable differences on matters of dogma. The ethical could be allowed into the public sphere while the dogmatic could be safely relegated to the private sphere. This was the logic behind restricting religion at the University of Sydney to the colleges in the 1850 s and the combination of secular state schooling supplemented by right of entry classes in the NSW public education system. It can be seen that this somewhat elegant solution to a religiously plural society was founded on a particular understanding of religion that tended to downplay dogma at the expense of the ethical. It created a secular public sphere only in the sense that there was common ground that bound citizens together, common ground that was religious in nature in an ethical not a dogmatic sense. It also strikes me as a peculiarly Anglican solution to the problem, or more specifically a liberal Anglican solution that looks back to the seventeenth century and the idea that religion had more to do with living a 'divine life' than with 'bookish learning', echoes of which one can find in the writings of Woolley. ${ }^{15}$

The only problem was that the Catholics recognised that, for them, such a division was nonsense and refused to adhere, establishing their own schools. This was because the Catholic understanding of religion and the secular was quite different from that of the Protestants in the colony. Matters of dogma, for Catholics, were not just an add-on-extra; they actually mattered. The introduction of 'secular' schooling, replacing an earlier system in which the state funded denominational schools, was a defining moment in the history of Australia because it put in place a system of religious segregation that would last for a hundred years.

\footnotetext{
${ }^{15}$ See for example John Smith, 'Of the true Way or Method of attaining to Divine Knowledge,' in Select Discourses, Cambridge, 1660, Ralph Cudworth, Mr Cudworth's Sermon Preached before the Honourable House of Commons at Westminster, March $31^{\text {st }}$ 1647, (Cambridge, 1852)
} 
The desire to create a public sphere that is secular in nature does not mean that religion and religious values do not influence the public matters of the day, only that they do not take an explicitly religious form that refers back to theology and dogma. It is in the public sphere that one looks to find expressions of moral order. One can read into public debates, which appear to be conducted in a religion free zone, the playing out of differences that have their roots in religion and theology. These debates had a religious dimension in the sense that they were founded on ethical concerns, on that part of religion that could be admitted, or 'smuggled into', the public sphere. In this sense religion is smuggled into the public sphere and helps to shape its moral order.

One of the areas where there was a strong religious dimension underpinning public debates was in economics and the issue of Free Trade and Protection. Free Trade and Protection are important because they expressed two different approaches to the issue that defined the character of what would evolve into Australian civilisation and culture.

One might expect that this economic issue would be an obvious manifestation of the new secular and materialist nature of Australia. Here, one would expect, would be found the expression of the modern utilitarian spirit of brash young Australians arguing purely in secular, technical and scientific terms. And yet nothing could be further from the truth. At its heart the battle between Free Trade and Protection was about differing ethical conceptions of the world, different ideas about moral order that had their foundations in religious understandings. Free Trade was based on an idea of providence that was related to the belief that the colonising spirit was part of God's mission for the world. ${ }^{16}$ The operation of commerce and trade destined

${ }^{16}$ Gregory Melleuish, 'Beneficent Providence and the Quest for Harmony: The Cultural Setting for Colonial Science in Sydney 1850 - 1890', Journal and Proceedings, Royal Society of New South Wales, 118 (1985): $167-80$ 
the world for better and higher things. This was the expression of a particular mode of Christian religiosity that went back to the argument from design and an emphasis on external factors as the foundation of religious belief. John Milbank has argued that the 'invisible hand' of political economy was essentially a form of theodicy, ${ }^{17}$ and one can see this in the colonial embrace of Free Trade in the middle of the nineteenth century. In the advocacy of free trade can be seen a fairly optimistic and theologically liberal view of humanity based on the belief that God, through Providence, was providing the means through which human beings could build a better world. When the possibility arose of a comet hitting the earth the Sydney Morning Herald announced that God would not allow such a thing to occur. ${ }^{18}$ Following Hilton's argument that there were two models of Free Trade in the first half of the nineteenth century it would be true to say the Australian colonists embraced the expansionist and cosmopolitan model rather than the evangelical variety. ${ }^{19}$ This is what one might expect in a new dynamic settler society. Natural theology still mattered, as is illustrated by William Hearn, an early professor at the University of Melbourne who wrote a manuscript on natural theology which argued that 'order pervades the Universe but it is an order that never fails and that is absolutely perfect in its various kinds. ${ }^{, 20}$ This emphasis on the universe as a harmonious order defined by God's laws that were designed for human beings to follow can also be found in Barzillai Quaife's The Intellectual Sciences, the first work of philosophy written in the colonies. ${ }^{21}$

\footnotetext{
${ }^{17}$ John Milbank, Theology \& Social Theory: Beyond Secular Reason, (Oxford: Blackwell, 1993), 26-45

${ }^{18}$ Sydney Morning Herald, 13 June 1857

${ }^{19}$ Boyd Hilton, The Age of Atonement: The Influence of Evangelicanism on Social and Economic Thought, 1795-1865, (Oxford: Oxford University Press, 1988) 69

${ }^{20}$ William Hearn, On Natural Religion, University of Melbourne Library, f. 72.

${ }^{21}$ Barzillai Quaife, The Intellectual Sciences, Vol 1. (Sydney: Gibbs, Shallard: 1872), especially 162-180
} 
Free Trade in the colonies rested ultimately on an optimistic form of natural theology. The key was to obey the Laws of God or nature and the result would be a free and harmonious world. John West argued that the future lay in the hands of the colonists and their willingness of otherwise to obey the dictates of Providence. ${ }^{22}$ The liberal Anglican John Woolley put forward a generous vision of human beings expanding their capacities and capabilities through the constant expansion of their capacity for sympathy with their fellow human beings. ${ }^{23}$ One of the best expressions of this optimistic vision of the future is to be found in the speeches of the Governor of New South Wales during the 1870s, Sir Hercules Robinson, speeches that subscribers in the colony paid to have published. Consider the following passage:

For with facilities for regular and constant railway communication with our neighbours the identity of the interests of adjoining colonies will day by day become more apparent, and petty provincial jealousies and rivalries will give place to those feelings of reciprocal sympathy which will tend to bind these Anglo-Saxon communities in Australia still more closely to each other, and to unite them in the advancement of the glorious mission of their race-the mission of peaceful commerce and human progress. ${ }^{24}$

Robinson makes only occasional references to religion but his vision is underpinned by a liberal and generous view of human nature that has its roots in a liberal religion that is essentially thisworldly and ethical in nature. Follow the paths of Providence and a better world will be the fate of humanity. The 1870 s was a decade of economic prosperity and hope as summed up by the

\footnotetext{
${ }^{22}$ John West, The History of Tasmania, A.G.L. Shaw (ed.) (Sydney, 1981), 533.

${ }^{23}$ Woolley, Lectures Delivered in Australia, 227-8

${ }^{24}$ Sir Hercules Robinson, Speeches delivered by His Excellency Sir Hercules G.R. Robinson G.C.M.G. during his administration of the government of New South Wales, (Sydney, 1879), 116
} 
Sydney International Exhibition of 1879. Future premier and prime minister George Reid put an entry into the poetry competition that concludes as follows:

And thus another lesson to mankind is taught,

Of amity by such co-operation wrought;

For here the fiercest competition for the prize,

The rival ardour to the general good allies.

This harmony of force was early understood,

By that first 'mong princes-ALBERT THE GOOD;

Bright harbinger of the restored, primeval plan,

That seeks the freedom yet the brotherhood of man! $!^{25}$

This is a generous view of the progress of humanity towards a more cooperative and peaceful world, one that is religious in the broad ethical sense. Hercules Robinson expressed a similar vision in these terms:

The condition of the whole world has in that period been transformed, mainly through the increased application of science to social life; but in no part of the globe has this transformation been more complete and striking than it has in Australia. Cook found this land a desolate waste, inhabited only by a few naked and hostile savages, and what is the prospect which meets the eye today? A country covered with flocks and herds-dotted with cornfields and vineyards - with bust cities and peaceful hamlets-with churches and schools-with railways and telegraphs; the harbours and coasts alive with steam vessels and other craft-and the land the happy home of over two millions of our own racewho are in the enjoyment of civil and religious liberty to as full extent as any people upon

\footnotetext{
${ }^{25}$ G H Reid, Lines addressed to New South Wales on the opening of the first Australian International Exhibition, (Sydney, 1879), 7.
} 
the face of the earth; and who, under these invigorating influences, have already so far advanced in all the outward and visible signs of civilization as to be about to collect this year examples of the products of labour, art, wealth, from every known country in the world into an International Exhibition. ${ }^{26}$

This Free Trade vision was at odds with the 'disciplinary' nature of religion that was discussed earlier in this paper. It can be argued that this optimistic vision of humanity was in many ways related to a desire to throw off the convict past. The convict taint would not permanently harm the colonies and human nature could be transformed under favourable conditions away from its sinfulness and depravity. Human beings did not need to cower before an authoritarian and paternalistic state but could become free and active agents able to take control of their destiny. God and nature would provide the means through which individuals could create a harmonious and happy world in which men and women would actively work together to create freedom, prosperity and happiness. Reid noted in his poem that Australia was free of war and civil strife. It is noteworthy that the foremost advocate of free trade in the twentieth century, Edward Shann, should have offered the choice to Australians of being either 'bond or free. ${ }^{27}$ If Free Trade was founded on a liberal and optimistic vision of human nature the opposite was true of Protection. Protection was founded on an explicit rejection of the optimistic vision of providence and a re-assertion of the sinfulness of the world. Its vision of the world looked back to Hobbes' state of nature and the need of Leviathan to intervene to restrain the evil ways of mankind. This comes out most clearly in the writings of the architect of Australian Protection David Syme. Syme's residual Calvinism was extremely powerful and it appealed to the moralistic caste of Australian religion and culture. It involved a deliberate and conscious

\footnotetext{
${ }^{26}$ Robinson, 227-8

${ }^{27}$ Edward Shann, Bond or Free? (Sydney: Angus \& Robertson, 1930)
} 
rejection of the notion of a beneficent providence at work in the world and its replacement by a view of humanity that emphasised its depraved and sinful nature. Consider the following passage of Syme on the nature of economic activity:

those who contend for the sufficiency of self-interest in industrial action seem to forget that some people desire to prosper and appear indeed for a while to prosper, at other people's expense; that, in fact, there are thieves and cheats in the world; that a large, and even respectable section of the community make their living, and even fortunes and titles, by making and selling fabrics that are guaranteed not to wear, by making and selling goods that are short of their proper weight and measure, and by making and selling adulterated food, drink, and even drugs that kill what they ought to cure. ${ }^{28}$

For Syme the economic realm is not governed by ethics or human decency but of struggle, strife and the worst aspects of human nature. It reminds one of Hobbes' state of nature:

But it is not so in the economic world. There it is the stronger against the weaker sex, the full-grown man against the infant; and when a man is down it is considered the proper thing to kick him and jump upon him... Whenever there are two individuals ...there must necessarily be two separate and antagonistic interests to be adjusted. ${ }^{29}$

Nor was Syme just suspicious of business people and merchants. He had an equally low opinion of politicians:

It is needless to say that such a body as this was not likely to care much for the liberties of the people; we, in fact, that the representatives of those days

\footnotetext{
${ }^{28}$ David Syme, Outlines of an industrial science, (Philadelphia, 1876), 34

${ }^{29}$ Syme, Outlines of an industrial science, 92
} 
were selfish in their aims, insolent in their bearing, and arbitrary and tyrannical in their acts. At first the servants of the constituencies, they soon assumed the air of masters; from being the protectors they became the oppressors of the people. They were intolerant of criticism in any shape, and the public they treated with sovereign contempt. ${ }^{30}$

Syme is full of these Hobbesian delights. Without a controlling state, for Syme, human beings would be in a constant state of war. The state must be there as an ethical tool, like, as Stuart Macintyre has observed, a harsh patriarchal father, to ensure that human beings are kept on a leash. ${ }^{31}$ And the point is that Syme matters, he was very influential, the Rupert Murdoch of his day. Through the Age he influenced both Victorian and early Commonwealth politics. Protection triumphed because of David Syme.

Protection was also popular amongst Catholics. One can read as early as the 1850 s a defence of what is termed fair trade and a repudiation of free trade as 'pure mammon worship' in the Catholic Freeman's Journal. ${ }^{32}$ That is not to say that there were not interests involved in the Free Trade/Protection debate. What it is to say is that is that the issue also came back to a fundamental divide in one's view of human nature, a divide that has quite clear religious roots. It may well be the case that Catholicism and Calvinism, in both their religious and more secular forms, were allies rather than enemies in the moulding of Australian culture. They perhaps came together in Australia in support of a fairly coercive (and Hobbesian) state founded on a

\footnotetext{
${ }^{30}$ Syme, D.. Representative Government in England: Its Faults and Failures, (London: 1881), 57

${ }^{31}$ Stuart Macintyre, A Colonial Liberalism: The Lost World of Three Victorian Visionaries, (Melbourne: Oxford University Press, 1991 ), 94

${ }^{32}$ Freemans Journal, 18 May 1859
} 
pessimistic view of human nature, and the need for a moral 'enforcer' that would guard against the failings of human nature.

All boys and girls are born little liberals or little conservatives but it does seem to be the case that the Free Trade Protection divide, between those who have a fairly optimistic view of the human condition and consequently trust individuals to behave decently and those who see human depravity everywhere and see no solution except in the coercive hand of the state, has its roots in the public application of ideals of moral order that were originally theological positions. It all comes down to how one understands the nature of moral order and the moral qualities of nature. Religious ideas have effectively been 'smuggled in' to what seems to be a rather mundane secular matter. This has happened because Free Trade and Protection were not primarily about technical economic issues but relate back to our 'deepest convictions.' Syme divided the world into two spheres, the moral sphere where humans prevail and an amoral sphere of necessity where the laws of nature acted without a concern for justice. The objective was to extend the realm of justice as far as possible and to tame and subjugate what an essentially amoral 'state of nature'. Through such means human hands can fashion a just social order, an order that was truly moral.

This brings the discussion back to Hancock and his argument regarding the medieval and therefore moral nature of the English. Both of the conceptions of moral order discussed above were nineteenth century creations. Both were incomplete and had weaknesses. In the 1930s the young Keith Hancock made a heroic effort to resolve those weaknesses and somehow to find a way beyond the dichotomous view of the world that they embodied. In Australia, published in 1930, and the essays that he wrote in the 1930s Hancock struggled with understanding the relationship between the moral order created by human beings which he identified with the idea of 'commonwealth' and the realm of necessity which he identified not 
with Hobbes but Machiavelli. Both Australia and England were concerned with moral issues, as opposed to Fascist Italy, because they pursued medieval ideals. Although not stated explicitly, this position would seem to imply that modern progress has created a hard and heartless world governed by the harsh and cruel maxims of Machiavelli. Hancock's 'politics of time' was thus not founded on an idea of progress such as had animated the Free Traders. Modernity was a cold and sometimes cruel place as Syme had asserted. But Hancock's ideal of commonwealth was the antithesis of Syme's controlling state and resembled in many ways the cooperative natural order towards which the Free Traders believed Humanity was being led. Hancock is a subtle writer and his work always demands careful reading. In the 1930s he explored the meaning of Machiavelli for the modern world. In his essay 'Machiavelli in Modern Dress' he argued that there are a number of propositions that are central to Machiavelli's work. These are:

- Men are bad. They 'never do good except through necessity.'

- 'Men are saved, politically, only by law.' Law is something that is imposed by force.

- In terms of international politics there is no legal society, no 'moral society', only a 'struggle for power'. ${ }^{33}$

It is worth noting that in Australia Hancock contrasted the attempt by Australians to create a moral order in Australia based on the 'medieval' idea of a just price with the reality of the lawless nature of the international order which could not care less about Australian justice. As he comments 'Australians have learned that it is more pleasant to dump than to be dumped upon' and that the means of attaining a 'fair price' for Australians may involve dumping on someone else. ${ }^{34}$

\footnotetext{
${ }^{33}$ Hancock, Politics in Pitcairn and other essays, 21

${ }^{34}$ W K Hancock, Australia, (London: Ernest Benn 1930), 97
} 
Hancock praises Machiavelli for his realism, for his frank appraisal of human nature. Hancock argues that this realism contemptuously ignores natural law, denies any connection between law and justice and places states in a world that is not bound by either law or morality. ${ }^{35}$ Hancock admires Machiavelli's clear vision but then attacks him for the contradictions that they entail. Again this is reminiscent of his approach in Australia where he takes a policy such wage fixation and points out that its consequences lead to the exact opposite of what the promulgators of that policy intended. ${ }^{36}$ If all men are evil, asks Hancock, what then are the mechanisms through which he can 'establish his ideal commonwealth of free warriors devoted to the public interest and obedient to law. ${ }^{37}$ The obvious answer, although Hancock does not mention it, is the establishment of a Hobbesian sovereign able to constrain human behaviour. Without such a mechanism, if one pushes the logic of Machiavelli to its conclusion it simply becomes incoherent:

But we part company with him when pushes his theory of interests to the point of denying the existence of a society of states, bound together-no matter how tenuously-by obligations of law and morality. We may include good faith, and not merely the reputation of good faith, among the tests of statesmanship. ${ }^{38}$

One of Hancock's primary objections to Machiavelli is that he cannot simply remain satisfied with a realist account of politics but soon enters back into the world of prescription:

\footnotetext{
${ }^{35}$ Hancock, Politics in Pitcairn and other essays, 37

${ }^{36}$ Hancock, Australia, especially Part II

${ }^{37}$ Hancock, Politics in Pitcairn and other essays, 37

${ }^{38}$ Hancock, Politics in Pitcairn and other essays, 39
} 
The word "ought" crept back into his histories and treaties. A prince ought to break faith. A prince ought to be ruthless...Machiavelli did not succeed in separating ethics from politics; he simply changed the ethics. ${ }^{39}$

If one uses reality, or the actual behaviour of human beings, as a guide to action the consequence must be to endorse unjust and vicious behaviour. On the other hand if one simply pursues idealistic norms without reference to what humans actually do the outcome will not be the creation of a just society. Hancock contrasts the two views, or what he calls 'maps', of politics, the 'Commonwealth' and the Machiavellian. The former is Medieval and the latter derives from the Renaissance. With his characteristic love of paradox and understanding of the contradictory nature of existence Hancock concludes that 'it is not yet possible to dispense with either map, the mediaeval map or the renaissance once.' He concedes that there is a perfect world:

$$
\begin{aligned}
& \text { That society would be a federation of nations living peacefully under a } \\
& \text { universally accepted rule of law which never found itself in jarring discord with } \\
& \text { justice. }^{40}
\end{aligned}
$$

This sounds surprisingly similar to the vision of the world espoused by the nineteenth century free traders, except that they assumed that this was the natural order towards which the world was moving as the consequence of progress. David Syme and the Protectionists, who understood the maxims that drove Machiavelli even if they did not name him, withdrew that vision of justice from the domain of humanity to within the borders of the state and gave the state the job of creating such a just order. In several places Hancock identifies this drive to create a 'Commonwealth' in Australia with the quest for mediaeval justice as expressed in the

\footnotetext{
${ }^{39}$ Hancock, Politics in Pitcairn and other essays, 46

${ }^{40}$ Hancock, Politics in Pitcairn and other essays, 49
} 
ideal of commonwealth of the Tudor Age. ${ }^{41}$ Australians may have thought that they were following modern ideas but, according to Hancock, they were the heirs of a much older tradition, a tradition that pre-dated 'modernity'.

In Australia, Hancock pointed to the failures of the early Commonwealth in terms of the inability of Australians to understand the realities of the political world, to appreciate Machiavelli. That did not mean, as the essays in Politics in Pitcairn indicate, that he gave up on the moral idealism of commonwealth. What this would seem to indicate is that Hancock effectively rejected the dichotomy on which political and economic discourse in Australia had been founded. There is no natural order that is just; nor is the amoral universe of Machiavelli satisfactory. Neither Reid nor Syme can provide a satisfactory answer to the question of how to create a just society. Until a just international order can be created, a realisation of the mediaeval commonwealth, one must be both Mediaeval and Machiavellian. Of course Hancock's association with the Milner group and their desire to create a just and peaceful international order is an indication of how seriously he took this challenge. ${ }^{42}$

Hancock was following the logic of a set of political and moral ideas that were originally theological in nature, but which became part of the 'secular' public sphere in Australia as they disassociated themselves from their religious origins and were 'smuggled into' the public sphere. They were, in this sense, both religious and secular. Although they may have made a claim to being 'scientific' it is clear that the whole discussion from the nineteenth century through to Hancock was essentially moral in nature. Hancock was right to take the idea of 'commonwealth' as his starting point because what was always sought was moral order, moral order that had medieval roots.

\footnotetext{
${ }^{41}$ Hancock, Politics in Pitcairn and other essays, 94-109

${ }^{42}$ Carroll Quigley, The Anglo-American Establishment, (San Pedro, 1981), 94
} 
Having developed the logic of the discussion to this stage the issue remains regarding that large area of the world which is outside of political, and hence ethical, control. The area under the sway of human morality in the shape of the state may roughly be described as the 'commonwealth'. The area outside of political control is essentially the realm of necessity. This is the place that can be identified with Machiavelli and his seemingly immoral practices.

But surely the commonwealth has its limits and if one pursues its moral imperatives only within the state then one is left with the problem of the wider moral consequences of those actions. What might make perfect moral sense within a particular political community may have consequences for other communities that are immoral. What we find in Hancock is an attempt to explore some of the contradictions of a world predicated on a commonwealth/Machiavellian realm dichotomy. Can commonwealth be extended into the international arena? Is the Machiavellian position consistent? Hancock is the seminal figure in Australian political thought because in his work there is an exploration of the whole idea of moral order as it had been established in the public sphere in Australia by both the free traders and the protectionists. If nature is essentially benign and the universe is working to fulfil God's plans then history becomes a form of progress and adherence to God's laws. If nature is essentially amoral then only human beings can create moral community. But what happens if human beings are bad? Then a higher authority is required to keep them in line. In a democratic age this cannot be a strong ruler but the state supposedly controlled by the people. This is essentially Syme's position.

But what happens if it doesn't turn out to be that simple? What if the attempt to create moral community turns out to have immoral consequences that harm those outside of that moral community? What happens if the Machiavellian world of amoral nature ceases to be an empirical description of the real world and becomes prescriptive? These are the questions that 
the young Hancock attempted to answer. This is why he wrote about commonwealth and Machiavelli.

Hancock's work must also be understood in terms of his involvement with the Milner group and their desire to create a moral commonwealth. ${ }^{43}$ England and Australia are medieval because of their concern with moral issues. Being modern means being Machiavellian and this entails a loss of ethical concerns and recognition of power and technique. And yet even modern (or medieval) 'welfare states' have to deal with the reality of living in a Machiavellian universe. Hancock's answer to this dilemma is essentially liberal in the sense that it means building moral community through law and cooperation. He is perceptive enough to recognise that in both commonwealth and Machiavelli there are paradoxes and inconsistencies that threaten their coherence. This preserved him from both Marxism and Fascism as being too simplistic in their appreciation of human nature.

What Hancock's response to the moral dilemmas of modernity illustrates is that the story of the search for moral community in Australia is not a simple one. It is most certainly not the story of the triumph of what can be described as 'modern secular ideas'. Rather it has its roots in traditional arguments about the nature of both human beings and their world that can be traced back to a religious understanding of the world. These traditional arguments had been secularised only in the sense that they had lost their location in a specific theological discourse and had become part of a more general moral discourse used in a public sphere marked by pluralism. Moral order deals with the deepest concerns of human beings; even a so called secular moral order comes to rely on religious ideas that have been smuggled in from the past. Hancock's great contribution was to demonstrate that neither position emanating from nineteenth century arguments about free trade and protection was ultimately satisfying as the

${ }^{43}$ See especially Lionel Curtis, Civitas Dei: The Commonwealth of God, (London: MacMillan 1938) 
foundation of moral order in the modern world. He was faced with the reality that, in an imperfect world, one had to be simultaneously both a supporter of commonwealth and a disciple of Machiavelli. There was no simple 'politics of time' that led either to a natural cooperative order or to a harsh immoral modernity which requires a controlling state to keep it in line. 